\title{
Study of amniotic fluid and its co-relation with pregnancy outcome in high risk pregnancies
}

\author{
Shazia Rashid*, Shivani Abrol, Farhat Jabeen, Perveen Fareed
}

Department of Obstetrics and Gynecology, Government Medical College Srinagar, Jammu and Kashmir, India

Received: 26 January 2017

Accepted: 04 February 2017

\author{
*Correspondence: \\ Dr. Shazia Rashid, \\ E-mail: shazia1715@gmail.com
}

Copyright: () the author(s), publisher and licensee Medip Academy. This is an open-access article distributed under the terms of the Creative Commons Attribution Non-Commercial License, which permits unrestricted non-commercial use, distribution, and reproduction in any medium, provided the original work is properly cited.

\begin{abstract}
Background: Amniotic fluid is an important part of pregnancy sac and helps in fetal development. There is a consistent association between low AFI and conditions like pregnancy induced hypertension, postdated pregnancy and IUGR resulting in poor fetal outcome. In fact, high risk patients with low amniotic fluid index need to deliver quickly. So, an assessment of amniotic fluid volume has become an important component of antenatal testing for the high risk pregnancy. The objective was to study the correlation between Amniotic fluid index less than $5 \mathrm{~cm}(\mathrm{AFI}<5)$ and adverse perinatal outcome in high risk pregnancies.

Methods: It was a hospital based prospective, comparative study. 150 high risk patients were selected from inpatient department of obstetrics and Gynecology Government Medical College Srinagar, Jammu and Kashmir, India over a period of one and half year. High risk pregnancies belonging to study group with $\mathrm{AFI}<5$ were demographically matched with high risk pregnancies with AFI $>5$ serving as comparison group. Perinatal outcome, rate of caesarean section and early intervention need were compared between the two groups.

Results: $77.3 \%$ women in study group underwent caesarean section as compared to $28 \%$ in control group to prevent adverse perinatal outcome. $60 \%$ babies in study group had APGAR score less than 6 at 1 minute compared to only $8 \%$ in control group. $61.4 \%$ babies in study group needed NICU admission compared to $10.7 \%$ in study group.

Conclusions: AFI is predictor of adverse outcome for high risk pregnancies. The early recognition alerts an obstetrician to prevent perinatal catastrophe if timely intervention is done along with antepartum and intrapartum fetal monitoring.
\end{abstract}

Keywords: AFI, High risk pregnancies, Perinatal outcome

\section{INTRODUCTION}

Amniotic fluid is an important part of pregnancy sac and helps in foetal development. ${ }^{1}$ Amniotic fluid surrounds the foetus and provides protective low resistance environment suitable for growth and development of foetus. ${ }^{2}$ It protects foetus from trauma, maintains body temperature and it has bacteriostatic proportion. Its pressure helps in reducing the loss of lung fluid and assist in pulmonary development ${ }^{3}$. It helps in development of musculoskeletal system by permitting foetal movements, growth and development of gastrointestinal system by swallowing amniotic fluid. ${ }^{1}$ Oligohydramnios is associated with a high rate of pregnancy complications and increased perinatal morbidity and mortality. ${ }^{1}$

Amniotic fluid volume rises to a plateau between 22 to 39 weeks of gestation reaching up to 700 to $800 \mathrm{ml}$, which corresponds to amniotic fluid index of 14 to $15 \mathrm{~cm}$. ${ }^{1}$ During last 30 years a wide range of tests have been introduced to determine the foetal wellbeing including AFI. Oligohydramnios is defined as AFI $<5 \mathrm{~cm}$. It is 
calculated as the sum of deepest vertical dimension in each quadrant of uterus on USG. ${ }^{4}$

Previously amniotic fluid volume was measured by dyedilution technique and direct quantification at the time of caesarean delivery, both methods are invasive cannot be used serially to evaluate high risk pregnancies. ${ }^{5}$ Ultrasound techniques the amniotic fluid index and single deepest pocket are currently available to detect oligohydraminos, to predict variable deceleration, risk for caesarean delivery for foetal distress and low Apgar score. 6

A finding of diminished amniotic fluid index is generally perceived as a sign of placental insufficiency. ${ }^{7}$ Sequelae of chronic oligohydraminos can be foetal demise, pulmonary hypoplasia, facial and skeletal deformities. Decreased liquor volume in labour may decrease volume of intervillous space which may predispose to umbilical cord occlusion, both of which increases the risk of foetal hypoxaemia and will affect the Apgar score of baby at birth. In high risk pregnancies, decline of AFI can be at a faster rate. ${ }^{8}$ It has been observed that antepartum or intrapartum $\mathrm{AFI}<5 \mathrm{~cm}$ is associated with significant rise of risk to LSCS for foetal distress and low Apgar at 5 minutes. ${ }^{9}$ Apgar score describes cardiorespiratory and neurological depression of new-born.

The umbilical cord compression during labour is common with oligohydraminos which increase the risk of caesarean delivery done for foetal distress and 5 minute Apgar of $<7 .{ }^{9}$ The reduction of amniotic fluid volume is associated with increase in induction of labour, stillbirth, non-reassuring foetal heart rate pattern, meconium aspiration syndrome and neonatal death. ${ }^{5}$ Determination of optimal time of delivery is necessary and labour should not be prolonged. ${ }^{10}$

There is a consistent association between low AFI and conditions like pregnancy induced hypertension, postdated pregnancy and IUGR resulting in poor foetal outcome. ${ }^{11}$ In fact, high risk patients with low amniotic fluid index need to deliver quickly. So, an assessment of amniotic fluid volume has become an important component of antenatal testing for the high risk pregnancy. The chronically stunned foetus is likely to have low amniotic fluid because of shunting of blood to brain and heart leads to decreased renal blood flow which subsequently leads to decreased urinary output. Because primary component of amniotic fluid in third trimester is foetal urine, on-going chronic stress is recognized as oligohydraminos. ${ }^{12}$

\section{Aims and objectives}

- To study whether AFI $<5 \mathrm{~cm}$ with high risk pregnancies is an appropriate threshold for pregnancy intervention to prevent adverse pregnancy outcome.
- Whether AFI is an important independent parameter to determine perinatal outcome in high risk pregnancies.

- To compare caesarean rates between patients having $\mathrm{AFI}<5 \mathrm{~cm}$ and $\mathrm{AFI}>5 \mathrm{~cm}$ in high risk pregnancies.

\section{METHODS}

\section{Study design}

This study was conducted in the postgraduate department of gynaecology and obstetrics.

This was a hospital based; prospective, comparative study conducted over a period of one and a half year from April 2013 to October 2014.

A total of one hundred and fifty patients were selected from inpatient department of Obstetrics and Gynecology. Subjects were demographically matched.

Patients belonging to study group include pregnancy induced hypertension, postdated pregnancy, Intrauterine growth retardation, chronic hypertension with: Gestational age >34 weeks, pregnancy with cephalic presentation, and pregnancy with intact membranes.

This study does not include the patients with following conditions; pregnancy with PROM, congenital abnormalities of fetus, polyhydramnios of any cause.

\section{Method}

75 high risk patients of $>34$ weeks pregnancy with an AFI $<5 \mathrm{~cm}$ were included in the study group followed by next 75 high risk pregnant patients with AFI $>5 \mathrm{~cm}$ with the same pregnancy complications in the control group. Ethical clearance was taken. A detailed history was taken, general physical examination, obstetrical examination was done in each patient. Other than routine investigations, abdominal sonography with AFI was done in each patient. The following outcomes were assessed: reactive/non-reactive non stress test, comparison of biophysical score between the two groups at admission, APGAR score $<6$, presence of meconium in amniotic fluid, perinatal morbidity (requirement of admission in NICU for 24 hours or more), pregnancy intervention (induction of labour and caesarean section), perinatal mortality.

\section{RESULTS}

Demographics of patients showed that mean age of present study population was 27.59 2 2.97years and mean duration of marriage was $2.74 \pm 2.63$ years.

As obvious from Table 2 there was significantly high rate of non-reactive NST in group with AFI $<5$ compared to group with AFI $>5(\mathrm{p}<0.001)$. 
Table 1: Association of low amniotic fluid index and high risk pregnancy.

\begin{tabular}{|c|c|c|c|c|}
\hline \multirow{2}{*}{ Risk factor } & \multicolumn{2}{|l|}{ Study group } & \multicolumn{2}{|l|}{ Control group } \\
\hline & Frequency (n) & Percent (\%) & Frequency (n) & Percent (\%) \\
\hline IUGR (symmetrical) & 10 & 13.3 & 13 & 17.3 \\
\hline IUGR (asymmetrical) & 27 & 36.0 & 24 & 32.0 \\
\hline PIH & 25 & 33.3 & 19 & 25.3 \\
\hline PD & 20 & 26.7 & 29 & 38.7 \\
\hline Chronic hypertension & 1 & 1.3 & 3 & 4.0 \\
\hline
\end{tabular}

Table 2: Relationship of AFI with non-stress list at admission $(n=150)$.

\begin{tabular}{|llll|}
\hline Characteristics & $\begin{array}{l}\text { AFI }<5 \mathrm{~cm} \\
\text { group }\end{array}$ & $\begin{array}{l}\text { AFI }>5 \mathrm{~cm} \\
\text { group }\end{array}$ & P value \\
\cline { 1 - 3 } Reactive & $25(45.5 \%)$ & $64(91.4 \%)$ & $<0.001$ \\
\hline Non-reactive & $30(54.5 \%)$ & $6(8.6 \%)$ & \\
\hline
\end{tabular}

Table 3: Comparison between induction rate and spontaneous labor.

\begin{tabular}{|lll|ll|}
\hline \multirow{2}{*}{ Labour } & \multicolumn{2}{l}{ Study group } & \multicolumn{2}{c|}{ Control group } \\
\cline { 2 - 5 } & Frequency & \% & \multicolumn{2}{l|}{ Frequency } \\
\hline Induced & 11 & 14.7 & 27 & 36.0 \\
\hline Not induced & 33 & 44.0 & 7 & 9.3 \\
\hline Spontaneous & 31 & 41.3 & 41 & 54.7 \\
\hline Total & 75 & 100 & 75 & 100 \\
\hline
\end{tabular}

Table 4: Relationship of AFI with mode of delivery $(n=150)$.

\begin{tabular}{|llll|}
\hline Mode of delivery & AFI $<5 \mathrm{~cm}$ & $\begin{array}{l}\text { AFI }>5 \\
\mathrm{~cm}\end{array}$ & $\begin{array}{l}\text { P } \\
\text { value }\end{array}$ \\
\cline { 1 - 3 } & $\mathbf{n = 7 5}$ & $\mathbf{n = 7 5}$ & \\
\cline { 1 - 3 } LSCS & $58(77.3 \%)$ & $21(28 \%)$ & \\
\hline Normal delivery & $17(22.7 \%)$ & $54(72 \%)$ & \\
\hline
\end{tabular}

As seen in Table 4 LSCS rate was significantly higher in group with $<5$ AFI ( $\mathrm{p}$ value=0.00).

Table 5: Indications for caesarean.

\begin{tabular}{|lll|}
\hline Indication of C-section & $\begin{array}{l}\text { AFI }<5 \mathrm{~cm} \\
\text { group }(\%)\end{array}$ & $\begin{array}{l}\text { AFI }>5 \mathrm{~cm} \\
\text { group }(\%)\end{array}$ \\
\hline Acute foetal distress & $39.2 \%$ & $12.0 \%$ \\
\hline Non progression of labour & $2.7 \%$ & $2.7 \%$ \\
\hline Oligohydramnios, IUGR & $31.1 \%$ & $5.3 \%$ \\
\hline $\begin{array}{l}\text { Cephalopelvic disproportion, } \\
\text { failure of induction }\end{array}$ & $5.4 \%$ & $8.0 \%$ \\
\hline
\end{tabular}

As seen in Table 5 the most common indication of LSCS was acute foetal distress followed by oligohydramnios and IUGR. As seen in Table 6 Apgar score of $<6$ was seen in 35 neonates in study group compared to one case in control group which was significantly high ( $\mathrm{P}$ value of $<0.001)$. Neonatal admission was also significantly high in study group $(\mathrm{P}=0.00)$. Perinatal mortality in group with AFI <5 was $21.3 \%$ compared to $0 \%$ mortality in group with AFI $>5$.

\section{Table 6: Relationship of AFI and neonatal outcome $(n=150)$.}

\begin{tabular}{|lll|}
\hline Characteristics & $\begin{array}{l}\text { Low amniotic } \\
\text { fluid index }\end{array}$ & $\begin{array}{l}\text { Amniotic } \\
\text { fluid index }\end{array}$ \\
\hline $\begin{array}{l}\mathbf{5} \mathbf{c m} \\
(\mathbf{n = 7 5})\end{array}$ & $\begin{array}{l}\mathbf{>} \mathbf{5 m} \\
\mathbf{( n = 7 5 )}\end{array}$ \\
\hline $\begin{array}{l}\text { Poor Apgar score at } \\
\text { 5 minute <6 }\end{array}$ & $35(46.7 \%)$ & $1(1.3 \%)$ \\
\hline $\begin{array}{l}\text { Normal of Apgar } \\
\text { score at 5 minute }>6\end{array}$ & $40(53.3 \%)$ & $74(98.7 \%)$ \\
\hline $\begin{array}{l}\text { Perinatal morbidity } \\
\text { required admission }\end{array}$ & $37(52.9 \%)$ & $1(1.3 \%)$ \\
\hline Perinatal mortality & $16(21.3 \%)$ & $0(0 \%)$ \\
\hline
\end{tabular}

\section{DISCUSSION}

AFI provides a quantitative result that is proportional to actual volume and more predictive than other methods. It is well-established that Oligohydramnios is associated with a high-risk of adverse perinatal outcome.

This study showed that patients with AFI $\leq 5$ with high risk pregnancy such as intra uterine growth retardation, post-dated pregnancy, chronic hypertension, and pregnancy induced hypertension showed poor perinatal outcome as compared to oligohydraminos in normal pregnancies. In this study $60 \%$ babies in study group had low Apgar score at birth $(<6)$ versus $8 \%$ of control group. Low 5 minute Apgar was seen in $46.75 \%$ babies in study group versus $1.3 \%$ in control group. Similar results were seen in study by Hasina Akhter and Guha K. ${ }^{13}$ Saima et al in their study found no difference in Apgar score between the two groups. ${ }^{16}$

In present study low BPP at admission was found more frequently in $\leq 5 \mathrm{~cm}$ AFI group with $77.3 \%$ of cases having BPP of 6 versus only $12 \%$ of controls. Same conclusion was drawn in study by Hovich $\mathrm{J}$ Jr. Vintizilious. ${ }^{14}$ In present study non-reactive non-stress test (NST) was found in $54.7 \%$ in study group versus $8.6 \%$ in control group with the conclusion more than half of AFI $\leq 5 \mathrm{~cm}$ group had signs of in utero hypoxia, 
consequently requiring intervention or more intense monitoring. Results were comparable with study by Rutherford, Pehlan et al which showed Oligohydramnios high rate of non-reactive FHR tracing (5.9 versus 0.94) which lead to intervention preventing adverse perinatal outcome. ${ }^{15}$ Low BPP at admission with non-reactive NST indicated requirement for intense foetal monitoring or early intervention in the form of CS and were not induced to minimize in utero exposure to hypoxia for prolonged period of time.

There was increased percentage among AFI less than $\leq 5 \mathrm{~cm}$ group where no induction was done, $44 \%$ versus $9.3 \%$ controls as termination in them either immediate or elective in form of CS based on low BPP and nonreactive NST. In our study AFI $\leq 5 \mathrm{~cm}$ group have increased caesarean rate $(77.3 \%$ versus $28 \%$ in controls) although both groups had same high risk factor. Similar results were found by Saima Iqbal and Asifa Nowreen. ${ }^{16}$ However Megann et al showed no significant difference in CS rate with the two groups. ${ }^{11}$ In present study more $\mathrm{CS} \leq 5 \mathrm{~cm}$ group were performed for AFD 35.5\% (18/59) as compared to AFI more than $5 \mathrm{~cm}$ group $28.57 \%(6 / 21)$ while indication of AFD with other in AFI $\leq 5 \mathrm{~cm}$ group was $18.64 \%$ versus $14.28 \%$ in control group this was in accordance with study by Ruthrford, Phelan et al and Zhang, James. ${ }^{15,17}$ However Conway, Deborah et al and Reinford, Adair did not find any difference in operative delivery being done for AFD and other indication between the two groups. ${ }^{18,19}$

In present study $61.4 \%$ of neonates in $\mathrm{AFI} \leq 5 \mathrm{~cm}$ group needed NICU admission as compared to $10.7 \%$ of AFI $>5$ group. Among neonates sent to NICU 52.9\% needed stay of $>24$ hours among AFI $\leq 5$ group and $1.3 \%$ in AFI $>5$ group. Bhagat, Indu in his study found NICU admission was present in $92 \%$ of $\mathrm{AFI} \leq 5$ group as compared to $71.4 \%$ in other group while $36 \%$ of AFI $\leq 5 \mathrm{~cm}$ needed stay of more than 2 days versus $24 \%$ in other group. ${ }^{20}$ In present study there was $10.7 \%$ of perinatal mortality overall. $21.03 \%$ among of AFI $\leq 5$ group had perinatal mortality while as $0 \%$ in other group. Among total of 16 perinatal deaths, 8 were stillbieths and remaining 8 were early neonatal deaths.

No neonatal mortality was seen in study done by Hasina akhtar and Sadia sultana. ${ }^{13,21}$ This was due to aggressive ante partum and intrapartum management that pregnancies with oligohydramnios received.

\section{CONCLUSION}

From the present study, it was concluded that AFI is predictor of adverse outcome for high risk antepartum or intrapartum ladies, the early recognition alerts an obstetrician to prevent perinatal catastrophe if timely intervention is done along with antepartum and intrapartum fetal monitoring and there is need for improvement in neonatal care.
Funding: No funding sources Conflict of interest: None declared

Ethical approval: The study was approved by the Institutional Ethics Committee

\section{REFERENCES}

1. Ever HF. Comparalibity of amniotic fluid index and single deepest pocket measurements in clinical practice. Aus NJ J Obs and Gynecol. 2003;43:75-7.

2. Volent E, Llimi G. Alteration of amniotic fluid and neonatal outcome. Acta Biomed. 2004;75(1):71-5.

3. Nicolini U, Fisk NM, Rodeck CLI. Low amniotic pressure in oligohydramnios- Is this cause of pulmonary hypoplasia. Am J Obstet Gynecol. 1989; 161(5):1098-101.

4. Brace RA. Normal amniotic fluid volume changes throughout pregnancy. Am J Obs Gynecol. 1989;161:382-8.

5. Casey BM. Pregnancy outcome after antepartum diagnosis of oligohydramnios at or beyond 34 weeks of gestation. Am J Obstet Gynecol. 2000;182:90912.

6. Murray E. Assessment of foetal growth size and well being. a guide to effective care in pregnancy and child birth. 3rd ed. Oxford university press; 2000:8092.

7. Desai PK. Decrease in amniotic fluid index in low risk pregnancy. Any significance? J Obstet Gynecol Ind. 2004;54(5):464-6.

8. Bank EH, Miller DA. Perinatal risks associated with borderline AFI. Am J Obstet Gynecol. 1999;180(6 Pt 1):1461-3.

9. Chauhan SP, Sanderson M, Hendrix NW, Magann EF, Devoe LD. Perinatal outcome and AFI in antepartum and intrapartum period- a meta analysis. Am J Obstet Gynecol. 1999;181(6):1473-8.

10. Kawasaki N, Nishimura H, Yoshimura T, Okamura H. A diminished intrapartum amniotic fluid index is a predictive marker of possible adverse neonatal outcome when associated with prolonged labor. Gynecol Obstet Invest. 2002;53(1):1-5.

11. Magnann F. Does an amniotic fluid index of $5 \mathrm{~cm}$ necessitate delivery in high risk pregnancies? Am J Obstet Gynecol. 1999; 180:1354-9.

12. Evere HF, Magnann. Oligohydramnios at term and pregnancy outcome. Fetal and maternal medicine review 2001;12(3):209-27.

13. Akhter H, Guha K, Daisy KP. Amniotic fluhid index in high risk pregnancies and pregnancy outcome. Dinajpur Med Col J. 2010;3(1):1-5.

14. Hovick TJ Jr, Vintzileos AM, Bors-Koefoed R, Campbell WA, Rodis JF, Nochimson DJ. Use of the foetal biophysical profile in severe oligohydramnios after preterm premature rupture of the membranes. J Reprod Med. 1989;34(5):353-6.

15. Rutherford SE, Phelan JP, Smith CV, Jacobs N. The four-quadrant assessment of amniotic fluid volume: an adjunct to antepartum foetal heart rate testing. Obstet Gynecol.1987;70(3Pt1):353-6. 
16. Iqbal S, Noreen A. Low Amniotic Fluid Index as a predictor of perinatal outcome in low risk pregnancies at term. Available from http://pjmhsonline.com/low_amniotic_fluid_index_a s_a_pr.htm

17. Zhang J, Troendle J, Meikle S, Mark A. Klebanof, Rayburn WF; Isolated oligohydramnios is not associated with adverse perinatal outcomes. BJOG. 2004;111(3):220-5.

18. Voxman EG, Tran S, Wing DA. Low amniotic fluid index as a predictor of adverse perinatal outcome. J Perinatol. 2002;22:282-5

19. Rainford M, Adair R, Scialli AR, Ghidne A, Spong CY. Amniotic fluid index in uncomplicated term pregnancy. Prediction of outcome. J Reprod Med 2001;46:589-92.

20. Bhagat M, Chawla I. Correlation of amniotic fluid index with perinatal outcome. J Obstet Gynaecol India. 2014;64(1):32-5.

21. Sultana S, Khan MNA, Akhtar KAK, Aslam M. Low amniotic fluid index in high-risk pregnancy and poor APGAR score at birth. J Coll Phys Surg Pak. 2008;18(10):630-4.

Cite this article as: Rashid S, Abrol S, Jabeen F, Fareed P. Study of amniotic fluid and its co-relation with pregnancy outcome in high risk pregnancies. Int J Reprod Contracept Obstet Gynecol 2017;6:819-23. 